\title{
New estimation of private returns to higher professional education and training
}

\author{
M. Alejandra Cattaneo * \\ Swiss Coordination Centre for Research in Education
}

\begin{abstract}
In this paper, a cost-benefit type of analysis is used to determine the rate of returns to education for the specific case of professional education and training (PET), differentiating for the two types of PET education offered in Switzerland. In contrast to the Mincer-type of analysis, the cost-benefits calculations allow to include the costs of education, direct and indirect, and the risk of unemployment. The net benefits of the PET program are estimated by calculating the discounted wages over the lifecycle, minus lost wages in case of unemployment, and the costs of education for individuals. These net benefits are then compared to those of individuals with upper secondary vocational education. The Swiss Labor Force Survey (SLFS) 1996-2009 is used in this analysis. The panel structure of the SLFS allows to calculate lower bounds of the wage gains, correcting thereby the endogeneity of the educational choice. The results show that, independent of the amount of financial support, individuals completing a PET have significant net-wage gains.
\end{abstract}

Keywords: professional training, wages, costs, rates of return on education

\section{Introduction}

The Swiss education system classifies tertiary level education into two types. On the one hand, there is tertiary education level A (ISCED 5A), which consists of universities and universities of applied sciences. On the other hand, there is tertiary education level B (ISCED 5B), which comprises professional education and training (PET). The main purpose of the latter is to be an extension of vocational education and training at upper secondary level with contents that are more complex, more specialized and in most cases built on extensive work experience. According to the Swiss Federal Statistical Office, approximately 23 percent of individuals with at least an upper-secondary vocational education degree completed a PET in 2008. Although PET leads to formal educational degrees, given its nature and organization, which will be described in greater detail in section 2 , it is sometimes confused with continuing or adult education programs, as PET programs are often part-time programs and also often financially supported by employers.

* Corresponding author: Swiss Coordination Centre for Research in Education, Enfelderstrasse 61, CH-5000 Aarau.E-mail: maria.cattaneo@skbf-csre.ch. 
In particular, this paper investigates the returns to PET, or tertiary education level B, in Switzerland by applying a cost-benefit analysis. What differentiates the PET programs from other types of tertiary education is that the individual costs associated with PET education, both direct and indirect, are higher than those associated with other types of tertiary education. This means that a simple Mincerian-type of rate of returns to education would overestimate the individual rates of return to PET programs. Moreover, participation patterns, financing arrangements and the starting age are extremely heterogeneous within the group of PET students. In this sense, the PET system is closer to continuing or adult education programs than to a formal tertiary level A education; hence, it needs to be studied separately. Additionally, this paper is most likely the first that differentiates between the different PET paths (professional colleges or professional examinations) when calculating the rates of return.

The main goal of this study is to answer the question of whether pursuing a PET degree generates positive rates of return to education taking into account the different possibilities of financing tuition fees and the opportunity costs, as well as using different ways of calculating the impact of completing a PET degree on the individual wage. For this purpose, the individual rates of return to PET relative to the alternative of having stopped at the level of upper-secondary vocational education are calculated. To compare net benefits, the direct and indirect costs, as well as the direct (higher earnings) and indirect benefits (e.g. lower risks of unemployment), of PET are taken into account. This is important for at least two reasons: first, it might help individuals make an informed decision when considering entering a PET program. Secondly, in contrast to ISCED 5A, PET programs in Switzerland are, to a much greater extent, privately financed. This fact is often criticized as a discrimination of PET relative to academic higher education. Therefore, it is useful for policy makers to know the returns to PET education in order to determine whether the lack of public financial support translates into low or negative rates of return on PET programs, a fact which will affect the demand for this type of education negatively.

There is a vast amount of literature on the returns to education (Mincer, 1959; Yoram Ben-Porath, 1967; Mincer, 1974; Card, 1999; Harmon et al., 2003; Psacharopoulos \& Patrinos, 2004). One of the major challenges when estimating the returns to education is to avoid a potential selection bias that arises when schooling decisions are endogenous. There are many different ways of trying to avoid the selection bias in order to identify the causal impact of education on earnings. Some studies use instrumental variables or natural experiments (Angrist \& Krueger, 1991, Angrist et al., 1996, Oreopolous, 2006), others employ fixed effects or study twin samples (Ashenfelter \& Krueger, 1994; Ashenfelter \& Rouse, 1998; Blundell et al., 2001; Bingley et al., 2009). In the field of adult education, some recent studies use field experiments to analyze the impact of training on wages (Schwerdt et al., 2011), others heterogeneous growth rates in earnings (Pischke, 2000) or matching methods assuming that the active and non-active persons in training that have the same observable characteristics are also similar in the unobservable characteristics (Leuven \& Oosterbeek, 2008). 
Although there is are no previous analyzes specifically addressing the rates of return to PET, we can borrow some of the methodology used to analyze the returns to adult or continuing education and job training to get estimates that are closer to the causal part of education on wages.

For this study, data from the 1996 to 2009 Swiss Labour Force Survey (SLFS) ${ }^{1}$ are used to calculate the returns to PET based on the cost-benefit model proposed by Wolter and Weber (1999), following the initial work of Psacharopoulos (1987, 1994). The cost-benefit model compares the relative and discounted advantage in earnings over the life-cycle for individuals who completed PET (distinguishing between professional colleges and professional examinations) and for individuals who only completed upper-secondary vocational education. The model also takes into account the direct and indirect costs of training and the wage losses due to different risks of unemployment. The panel structure of the SLFS data is used to control for potential self-selection. The analyzes show, that when taking selection into account, the wage effect of PET is significantly smaller than when we do not control for endogeneity (about $5 \%$ as opposed to about $21 \%$ ) and that attending a professional college provides greater returns than taking a professional examination. The net benefits over the life cycle of completing a PET program are almost always positive, independently of the costs and discount rates. Only in very specific scenarios with very low wage effects and high individual costs, the rates of return to PET can be negative.

The paper is organized as follows: Section 2 briefly describes the Swiss vocational education and training system. Section 3 presents the data and the descriptive evidence. Section 4 shows the empirical methods and the impact of PET on wages, and Section 5 concludes.

\section{Professional Education and Training}

After finishing compulsory schooling, students wishing to continue with their education can choose between on the one hand general education, which consists of selective schools (leading to a Baccalaureate degree) and specialized schools, and on the other hand vocational education and training (VET), which leads to a Federal VET Diploma (with the possibility of acquiring additionally a Federal Professional Baccalaureate degree that guarantees free entry to one of the universities of applied sciences). Most VET programs combine school- and work-based education and training (apprenticeship), meaning that the students attend school part of the time and spend the rest of their time doing working and learning in host companies. Approximately $60 \%$ of Swiss compulsory school graduates choose to follow this type of education.

Based on UNESCO's International Standard Classification of Education (ISCED), tertiary-level education in Switzerland may be broken down into two main categories. There is tertiary-level A education (i.e. ISCED 5A), which includes the (aca-

1 The author thanks the Federal Statistical Office for the permission to use the data from the Swiss Labour Force Survey. 
demic) universities, universities of applied sciences and universities of teacher education. Then, there is tertiary-level B (i.e. ISCED 5B), which consists of professional education and training. According to the Federal Vocational and Professional Education and Training Act, the goal of PET programs is to enable the transfer and acquisition of «competencies needed to carry out the complex tasks and decision making associated with a given occupational activity». Unlike universities or universities of applied sciences, students do not need a baccalaureate in order to be admitted to a PET program. The usual entry requirements include an upper-secondary level diploma and for PET examinations several years of professional experience in the occupation of interest.

There are two types of PET degrees: First, degrees of professional colleges (höhere Fachschulen) and secondly two forms of national professional examinations: the Federal PET Diploma Examination (Berufsprüfung zum eidgenössischen Fachausweis) and the Advanced Federal PET Diploma (Höhere Fachprüfung zum eidgenössischen Fachdiplom). The difference between the two types is that for professional colleges the entire study program is federally recognized. They are based on curricula developed and issued by the professional colleges themselves in cooperation with professional organizations. Students may enroll either full time or part time, and depending on the type of education it takes two or three years to complete the degree. Potential students need to have an upper-secondary education degree and, in some cases, also need work experience.

For the professional examinations, only the content and mode of execution are federally recognized. Preparatory courses for these examinations are voluntary and regulated by occupational associations. Most of the preparation for the examinations is done on a part-time basis. To take a professional examination, students are required to have an upper-secondary level degree and several years of work experience in the occupational field of the exam.

Cantons are primarily responsible for implementing and financing PET programs. PET tuition costs vary greatly depending on the field and the provider. About 40 percent of the costs of part-time programs and 80 percent of the costs of full-time programs for professional college degrees are publicly funded. In the case of professional examinations, a part of the direct and indirect costs is usually covered by the employer. ${ }^{2}$

\section{Descriptive Evidence}

In this study, data from the SLFS are used. The SLFS has been drawn annually since 1991 by the Swiss Federal Statistical Office and provides information on demographic and labor market characteristics of the Swiss adult population. Each year, a representative sample of about 20,000 to 45,000 Swiss households (depending on the year) is chosen randomly from the telephone book and one of the household

2 For further details, see SKBF (2010). 
members is interviewed by phone. For this study, we will use the last 14 waves, which run from 1996 to 2009. ${ }^{3}$ The SLFS is a rotating panel, and each participant is interviewed for up to five consecutive years in the second quarter of the year (between April and June ${ }^{4}$ ). Due to sample attrition, however, it is not possible to observe the full five-year period for most of the surveyed individuals. Therefore, for each person in our data set, we have between 1 and 5 records, each one of them corresponds to each of the waves in which the individual participated. The observations contain information on demographic, education, income and employment characteristics for the current year plus information on past employment for the unemployed and individuals out of the labor force. The observation periods of different individuals overlap, meaning that some individuals may be beginning the interview process while others who entered the sample in previous years are in their second, third or final round. The panel data structure of the SLFS is particularly useful when observing a part of the respondents' working and education history. Different samples were created depending on the question to be addressed. Furthermore, individuals with only compulsory education or those who already have a university degree were dropped from the sample. This was done in order to constrain our sample to PET degree holders and potential PET holders. ${ }^{5}$ We further constraint our sample to respondents older than 25 and younger than 65 , regardless of labor market status. After deleting observations with missing information, we have a final sample of 148,816 observations, which correspond to 64,841 individuals .

The SLFS asks all respondents about their highest level of education achieved. Individuals are defined as having a PET degree if they declare to have completed one of the three following educational categories: PET with a national examination (Meisterdiplom or Eidgenössischer Fachausweis), technical college, or professional college.

Of all respondents in the sample, $48 \%$ are male and $76 \%$ are of Swiss nationality and approximately $20 \%$ have a PET degree. Out of the $20 \%$ individuals who completed a PET program, $66 \%$ are male, almost $80 \%$ are Swiss, and $72 \%$ live in the German-speaking region (Table 1). We also notice differences in the labor market outcomes, with $42 \%$ of individuals with a PET degree occupying a management position and having annual earnings that are roughly $20,000 \mathrm{CHF}$ higher than wages of individuals without a PET degree (about 100,000 CHF against 80,000 CHF). ${ }^{6}$ These descriptive results also hold when we control for other observable character-

3 The first three waves are not used because one of the questions needed for this analysis was not asked before 1996.

4 This changed in 2010 , but it is irrelevant for our study sample

5 PET examinations are also taken, in specific areas like tax consultants or controllers, by people who have already a university degree. However, we excluded people with tertiary A degrees from our sample because they would have required a different reference category in order to calculate a meaningful rate of return to a PET degree.

6 Earnings are based on gross annual wages converted into real full-time equivalent wages in this analysis. The 2005 Consumer Price Index from the Swiss Federal Statistical Office is utilized to deflate and inflate the wages of the different years of the SLFS. 
istics using multivariate analyses. The results in Table 2 show, that men have a 12 percentage points higher probability of pursuing a PET program, and that Swiss nationals and individuals from the German-speaking region are 5 percentage points more likely to pursue a PET. With respect to wages, individuals who obtained a PET degree earn, on average, $25 \%$ more than individuals who only have stopped after their upper-secondary level education. When we distinguish between professional colleges (PC) and professional examinations (PE), it is notable that men have an almost 10 and 5 percentage points higher probability than women of graduating from a $\mathrm{PC}$ or attempting a PE respectively. For PC in contrast to PE there is no significant difference between the French and Italian speaking part of Switzerland and the German speaking part of Switzerland. ${ }^{7}$

In addition, by taking advantage of the panel structure of the data, it is possible to compare the labor market outcomes of respondents before and after completing the PET program, if the completion of the PET program fell into the individual survey period. This means that only those individuals who obtained their degree during their participation in the SLFS can be used for the analysis. The identification of these individuals was twofold: first, those individuals who, during the interview years, change their answer to the question about the highest level of education from an upper-level secondary to a PET remained in the data set. Second, the sample was further restricted, retaining only those who answered positively to the question of whether they have successfully completed some type of education program in the last 12 months. On average, it took individuals in the sample about two years to complete the degree. When we analyze the labour market outcomes of individuals before and after completing a PET program, we find that the average earnings are 6 percent higher after completing the degree; however, this difference is not statistically significant (the wages before and after completing the PET are about 84,000 $\mathrm{CHF}$ and 90,000 $\mathrm{CHF}$ respectively ${ }^{8}$ ). One has to keep in mind, that when restricting the observational period to a maximum of five years, the estimates must be interpreted as short-term effects of education and that in the long run, higher effects of PET degrees can be possible.

\section{Empirical methodology and results}

The main purpose of this paper is to estimate the returns to PET, taking into account the direct and indirect costs of education and the extra benefits of additional education, such as a lower risk of unemployment. In order to do so, calculations are based on a cost-benefit model proposed by Wolter and Weber (1999). The model calculated the net-present value of the discounted earnings over the life cycle, minus the discounted direct costs of pursuing a PET program and the discounted value of wage

7 It should be noted that these numbers can not be interpreted as being causal. They are correlations after having controlled for some observable characteristics.

8 These numbers were obtained by simply calculating the arithmetic mean of the wages before and after the PET, for the sample of individuals who completed the PET during the interview period. 
losses due to unemployment. Then, the rate of return to education is calculated by comparing the net present value for individuals with a PET degree and for individuals with the next lowest level of education, which in this case is upper-secondary VET education. Formally, we estimate the following equation:

$\mathrm{PV}_{\mathrm{PET}}=\left[\sum \mathrm{W}_{\mathrm{PET}} *(1+\mathrm{i})^{-\mathrm{t}}\right]-\left[\sum\left(\mathrm{U}_{\mathrm{PET}} * \mathrm{~V}_{\mathrm{PET}}\right) *(1+\mathrm{i})^{-\mathrm{t}}\right]-\left[\sum \mathrm{C}_{\mathrm{PET}} *(1+\mathrm{i})^{-\mathrm{t}}\right]$

where $P V_{P E T}$ is the net present value of a PET program, $W$ are wages, $U$ is the unemployment rate, $V$ is the lost income in case of unemployment (which is the wage multiplied by the replacement rate of the unemployment insurance $\left.{ }^{9}\right), i$ is the discount rate (which equals either the market interest rate or stands for the individual time preference) and $C$ are the direct costs.

We estimate the earnings over the life cycle $(W)$ using a Mincer-wage regression, including a dummy variable for PET that equals one if the individual completed a PET degree and zero otherwise, as an explanatory variable.

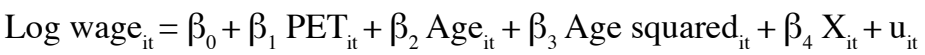

where $\beta_{1}$ is the rate of return to PET; $X$ is a vector of explanatory variables including gender, tenure, and place of residence; and $u$ is an error term with mean 0 that can be decomposed into a time-fixed component $\alpha$; and a time-varying component, $e_{\mathrm{i}}$. The predicted wage for each age is then calculated as $\exp \left(\widehat{\beta}_{0}+\widehat{\beta}_{1} \mathrm{PET}_{\mathrm{it}}+\widehat{\beta}_{2} \mathrm{Age}_{\mathrm{it}}+\widehat{\beta}_{3}\right.$ Age squared $\left._{\text {it }}\right) * \exp \left(\widehat{\sigma}^{2}\right)$.

The problem of estimating equation (2) by ordinary least squares bears the risk of potential selection bias. Individuals who choose to enter a PET program and individuals who do not may differ in their unobserved characteristics, such as ability, ambition, and motivation. Therefore, it might be that individuals who complete a PET education would earn more regardless of whether they obtain a PET degree or not. If this is the case, direct estimation of equation (2) would overestimate the rate of return to PET. In this instance, overestimation occurs because it is impossible to know what might have happened to the wages of individuals who did not receive a PET education had they chosen to pursue one. Thus, equation (2) assumes that the rate of return for a PET degree will be the same for individuals who earned a PET degree and those who did not.

To control for at least the part of unobserved heterogeneity that is time-invariant, we estimate the rate of returns to PET using our longitudinal data with a fixed-effects regression formula:

Log wage $_{i t}-\overline{\log }_{\text {wage }_{i}}=\beta_{1}\left(\mathrm{PET}_{\mathrm{it}}-\overline{\mathrm{PET}}_{\mathrm{i}}\right)+\beta_{2}\left(\mathrm{X}_{\mathrm{it}}-\overline{\mathrm{X}}_{\mathrm{i}}\right)+\left(\mathrm{e}_{\mathrm{it}}-\overline{\mathrm{e}}_{\mathrm{i}}\right)$

9 The standard replacement rate is $70 \%$ and $80 \%$ if wages before unemployment were under a certain threshold or if the unemployed person has children. 
where $\overline{\log }$ wage $_{\mathrm{i}}=1 / \mathrm{T} \sum \log _{\mathrm{wage}}, \overline{\mathrm{PET}}_{\mathrm{i}}=1 / \mathrm{T} \sum \mathrm{PET}_{\mathrm{i}}$ and $\overline{\mathrm{X}}_{\mathrm{i}}=1 / \mathrm{T} \sum \mathrm{X}_{\mathrm{i}}$. This method removes permanent unobservable individual differences from the equation. ${ }^{10}$ While removing correlated and time-invariant unobserved effects, the drawbacks of this method are as follows: i) it is not possible to estimate the effects of endogenous variables that do not vary across time, ii) by using the within variation method alone, potential measurement error in PET might become relatively more important, which would bias the results towards zero; and this method does not control for a correlation between $\mathrm{e}_{\mathrm{it}}$ and $\mathrm{PET}_{\mathrm{it}}{ }^{11}$

In the literature on continuous or adult education, Ordinary Least Square (OLS) estimates are typically larger than those obtained with fixed effects (Leuven \& Oosterbeek, 2008). Therefore, we will use the OLS estimates of the rates of returns to PET as the upper bound and the fixed effects rates of return as the lower bound in order to calculate the earnings over the life cycle $(W)$. The results of both regressions are presented in Table 3, differentiating between professional examinations and professional colleges. According to the OLS regression, individuals with a PET degree earn, on average about 20 percent more than individuals without one. ${ }^{12}$ Even though both types of PET (PC, PE) have a clear economic advantage in comparison to secondary VET education, there is a significant difference between the rates of return for PC and for PE. ${ }^{13}$ The latter earn, on average, 9\% less than their professional colleges' counterparts. ${ }^{14}$ Therefore, we will calculate wages over the life cycle using the different coefficients for each type of PET, differentiating between returns to PC and returns to PE. Keeping in mind the possibility that due to the selection bias the OLS estimates overestimate the wage effect of both kinds of PET programs, we also calculate the returns using the fixed effects model. In this model, the wage effect of PET is much smaller: about 3 percent for PE and 8 percent for PC..$^{15}$ The smaller wage gain with the fixed effect model indicates that at least some part of the large OLS coefficient is likely to be caused by selection. However, the coefficient has to be interpreted as a lower bound for the real causal impact of PET on earnings, due to the pitfalls mentioned above and also to the possibility that the wages in the years im-

10 For examples of studies that follow this approach, see Barron et al. (1993), Booth (1993), Frazis \& Loewenstein (2005), Parent (1999) and Veum (1995)

11 A possible solution would be to use instrumental variables. However, a credible source of exogenous variation for studying in PET programs was not available.

12 This high rate of return might be partly capturing the effect of on-the-job training, due the fact that more educated workers tend to receive more training by their employers than less educated ones (Bassanini, 2003). The returns are also quite high relative to the returns to other types of formal education in Switzerland, which range between 6-9\% per year of schooling (see SKBF, 2010, p. 315).

13 We calculate a modified version of Equation (2), as follows: Logwage $\mathrm{it}_{\mathrm{it}}=\beta_{0}+\beta_{11} \mathrm{PC}_{\mathrm{it}}+\beta_{12} \mathrm{PE}_{\mathrm{it}}+\beta_{2}$ Age $_{\mathrm{it}}+\beta_{3}$ Age squared $_{\mathrm{it}}+\beta_{4} \mathrm{X}_{\mathrm{it}}+\mathrm{u}_{\mathrm{it}}$.

14 Note, however, that if we assume that it takes two years of full-time study to obtain a PC degree and less than one year to prepare for a PE, then the returns are more or less similar or even smaller for PC after one year of study (the rate of returns to a PC degree per year of study would be 0.125 against 0.16 for a PE degree).

15 The small coefficients for PC and PE are in line with those obtained by Schwerdt et al. (2011) when analyzing the effect of adult education on wages (they find a wage increase between $1 \%$ and $6 \%$ depending on methods and covariates). 
mediately following the completion of the PET might not adjust quickly to the new education level for various reasons. Nevertheless, we can use the OLS coefficients as our upper and the fixed effects coefficients as our lower level bounds to calculate the discounted life time earnings for individuals with a PET degree and individuals and comparing them to the life-time earnings of individuals with just an upper-secondary level education. To calculate the discounted lifelong earnings $\left(\sum \mathrm{Wt} *(1+\mathrm{i})^{-\mathrm{t}}\right)$, we use a discount rate (i) of 3 percent as the standard. ${ }^{16}$

Individuals finish their PET degrees at different ages depending on the type of PET (PC or PE) and on the field of study. Individuals who attend a PC tend to be younger and complete their studies approximately the age of 25 . However, individuals who take a PE are generally older, around the age of 32 (Schärrer et al., 2009). Therefore we will consider different starting ages, when calculating the in the net present values of PC and PE programs. The unemployment rate $(U)$ is obtained from the SLFS, and is about 1.6 percent for individuals with PET education and 2.2 percent for individuals with an upper-secondary vocational education. ${ }^{17}$ The lost income due to unemployment $(V)$ in equation (1) is calculated as $\mathrm{Wt}^{*}(1-0.7)$.

When calculating the costs $(C)$, we use the tuition fee costs reported by Seiler et al. (2008). According to this study, the average tuition amounts to $10,055 \mathrm{CHF}$ for students in professional colleges and to about 7,800 CHF for students who take the professional examinations.$^{18}$ To calculate the opportunity costs of PET programs we assume that it takes two years (four semesters) to complete a professional college degree and one and a half years (three semesters) to prepare for a professional examination. ${ }^{19}$

With these assumptions, life earnings are calculated using Equation (1). To analyze the net benefits of obtaining a PET degree under different scenarios, the age/ earnings profiles are calculated using the age and age square coefficients from the OLS equation, the rates of return from Table 3 and an additional intermediate rate of return of 15 percent for PC and 10 percent for PE. Selected results are shown in Tables 4 and 5, differentiated by PC and PE.

Then, the net benefits of four different costs-scenarios are analyzed: on one extreme, what is assumed to be the most realistic in the case of PC is that the student does not work and the student pays the whole tuition costs. Then, the two scenarios that are more relevant for students who take the PE are: working fifty percent and paying fifty percent of the tuition costs or working eighty percent and paying fifty

16 This seems to be a realistic for the current situation of no inflation and nominal interest rates that are near zero. However, we also used 5 percent and 7 percent interest rates to test the sensitivity of our results to the standard discount rate. These findings are discussed in the results section.

17 These numbers do not vary much with age.

18 The direct costs highly depend on the field and whether the individual attends professional colleges or is taking a diploma. For example, individuals studying hotel management in a professional college have self-reported costs of about 7,600 CHF per semester (much of this constitutes board and lodging), whereas individuals in professional health colleges have costs of about 2,000 CHF (Schärrer et al., 2009).

19 The length of the studies varies between most professional college courses and professional examinations. Most diplomas are obtained after 2-3 semesters, whereas obtaining a PET degree in a professional college takes more than 4 semesters. 
percent of tuition costs. ${ }^{20}$ The other extreme of paying nothing at all and working full-time is the most unrealistic but is used as a benchmark for comparative reasons.

The results in Table 4 show that in all four cost scenarios, the net benefit of graduating from a PC is positive. With an intermediate wage increase $\left(\beta_{1}\right)$ to PET of 15 percent, individuals with a PC degree have a rate of return on education that lies between 10 and 16 percent. Cost-scenario 1 is the most sensitive to changes in the assumptions and models: the rate of return turns negative if the wage increase due to the PC degree is as low as $6 \%$, the discount rate is above 4 percent or if the starting age is above 30 years. The only situation in which cost-scenario 2 turns negative is when the wage effects of the PC degree would fall below 3 percent. With wage effects above our lower bound of 7 percent, the net benefits are always positive, independent of the cost scenario, the starting age or the discount rate.

Table 5 displays the results for PE. For cost-scenario 2, the net benefits turn positive as soon as the wage effect is above 3.5 percent. With wage effects above 6 percent, the net benefits remain positive even with discount rates (i) as high as $7 \%$. If the person is older than 40 years of age when finishing the PE program, the wage effect has to be above $6.5 \%$ to make taking the exam worthwhile.

In summary, PC degrees are almost under any cost and wage scenario a good investment. The same is true for PE degrees, if we take the more realistic cost-scenarios. For both PCs and PEs, the factor most affecting the rates of return on education is, apart from the wage effects, the financing scheme of the opportunity costs.

\section{Conclusion}

In this paper, the rates of return on education for degrees of professional education and training are calculated using different calculations of effects of education on wages and using different scenarios for the direct and indirect costs of education. Specifically, this paper attempts to compare the lifetime earnings of PET degree holders, differentiating for the first time between professional colleges and professional examinations, with the lifetime earnings of individuals with the next lowest level of education, an upper-secondary level vocational training, in a framework that considers both the Mincerian-type rates of returns to education, the direct and indirect costs of education and the relative risk of unemployment associated with PET programs. To calculate these rates of return on PET programs, panel data from the Swiss Labor Force Survey for the period 1996-2009 is used.

The results show that only in the case of very low wage effects (in the order of $3 \%$ or less) and the most unfavorable cost scenarios, the net benefits of completing a PET degree turn negative. In other words, the private costs of following a PET program are almost always compensated by the wage gains associated with a PET degree.

20 According to Schärrer et al. (2009), more than fifty percent of the students receive financial support from their employer. This figure largely depends on the size of the firm. 


\section{References}

Angrist, J. D. \& Krueger, A. (1991). Does compulsory schooling attendance affect schooling and earnings? Quarterly Journal of Economics, CVI (4): 979-1014

Angrist, J. D., Imbens, G. W. \& Rubin, D. (1996). Identification of causal effects using instrumental variables. Journal of the American Statistical Association, XCI: 444-455

Ashenfelter, O. \& Krueger,A. B. (1994). Estimates of the economic return to schooling from a new sample of twins. American Economic Review, 84: 1157-1173

Ashenfelter, O. \& Rouse, C. (1998). Income, Schoolings, and Ability: Evidence from a new sample of identical twins. Quarterly Journal of Economics, 113: 253-284

Bassanini, A. (2003). Solving the training divide. OECD Observer, 240/241: 43-45

Barron, J. M., Black, D. A. \& Loewenstein, M. A. (1993). Gender differences in training, capital, and wages. Journal of Human Resources, 28(2): 343-364

Ben-Porath, Y.(1967). The production of human capital over the life cycle. Journal of Political Economy, 75: 352-365

Bingley, P., Christensen, K. \& Walker I. (2009). Decomposing the changing returns to schooling by explaining twin differences. Social Policy and Welfare Services Working Paper, 06:2009

Blundell, R.; Dearden, L. \& Sianesi, B. (2001). Estimating the Returns to Education: Models, Methods and Results. London School of Economics, Centre for the Economics of Education Paper

Booth, A. (1993). Private sector training and graduate earnings. Review of Economics and Statistics, 75(1): 164-170

Card, D. (1999). The causal effect of education on earnings. The Handbook of Labor Economics, Vol. 3.

Frazis, H. \& Loewenstein, M. A. (2005). Reexamining the returns to training: functional form, magnitude, and interpretation. Journal of Human Resources, 15(2): 453-476

Harmon, C.; Oosterbeek, H. \& Walker, I. (2003). The Returns to Education A Review of Evidence, Issues and Deficiencies in the Literature. Journal of Economic Surveys, 17 (2): 115-156

Leuven E. \& Oosterbeek, H. (2008). An alternate approach to estimate the wage returns to private-sector training. Journal of Applied Econometrics, 23: 423-434

Mincer, J. (1974). Schooling, experience and earnings. New York: NBER

Oreopoulos, P. (2006). Estimating average and local average treatment effects of education when compulsory school laws really matter. American Economic Review, 96 :152-175

Parent, D. (1999). Wages and mobility: the impact of employer-provided training. Journal of Labor Economics, 17(2): 298-317

Pischke, J.-S. (2001). Continuous training in Germany. Journal of Population Economics, 14: 523-548

Psacharopoulos, G. (1987). The cost-benefit model. In: G. Psacharopoulos (Ed.): Economics of Education: Research and Studies. Oxford: Pergamon

Psacharopoulos, G. \& Patrinos, H. A. (2004). Returns to investment in education: a further update. Education Economics, 12(2): 111-134

Schärrer, M.; Fritschi, T.; Dubach, P. \& Oesch, T. (2009). Finanzflüsse in der höheren Berufsbildung. Eine Analyse aus der Sicht der Studierenden. Bern: Büro BASS

Schwerdt, G.; Messer, D.; Woessmann, L. \& Wolter, S. C. (2011). Effects of Adult Education Vouchers on the Labor Market: Evidence from a Randomized Field Experiment. IZA Discussion Paper, No. 5431

Seiler, P.; Muggli, M. \& Sommer, P. (2009). Analyse der Finanzflüsse in der höheren Berufsbildung. Bern: Price Waterhouse Coopers

[SKBF] Swiss Coordination Centre for Research in Education (2010). Bildungsbericht Schweiz 2010. Aarau: SKBF

Veum, J. R. (1995). Sources of training and their impact on wages. Industrial and Labor Relations Review, 48(4): 812-826

Weber, B. A.; Wirz, A. M. \& Wolter S. C. (2001). Switzerland. In: C. Harmon, I. Walker \& N. Westergaard-Nielsen (Eds.): Education and Earnings in Europe - A Cross Country Analysis of the Returns to Education, Cheltenham: Elgar

Wolter, S. C. \& Weber, B. A. (1999). On the measurement of private rates of return to education. Jahrbücher für Nationalökonomie und Statistik, 218/5+6 


\section{Appendix: Tables}

Table 1: Descriptive statistics

\begin{tabular}{|c|c|c|c|c|c|c|}
\hline & PET & $\mathrm{PC}$ & PE & $\begin{array}{l}\text { Second- } \\
\text { ary VET }\end{array}$ & Total & PET-VET \\
\hline Age & $\begin{array}{c}44.4 \\
(0.05)\end{array}$ & $\begin{array}{c}44.51 \\
(0.064)\end{array}$ & $\begin{array}{c}44.27 \\
(0.071)\end{array}$ & $\begin{array}{l}44.86 \\
(0.03)\end{array}$ & 44.75 & $*$ \\
\hline Male & $\begin{array}{c}0.69 \\
(0.002)\end{array}$ & $\begin{array}{c}0.68 \\
(0.003)\end{array}$ & $\begin{array}{c}0.69 \\
(0.004)\end{array}$ & $\begin{array}{c}0.5 \\
(0.001)\end{array}$ & 0.54 & $*$ \\
\hline Swiss & $\begin{array}{c}0.79 \\
(0.002)\end{array}$ & $\begin{array}{c}0.76 \\
(0.003)\end{array}$ & $\begin{array}{c}0.84 \\
(0.003)\end{array}$ & $\begin{array}{c}0.75 \\
(0.001)\end{array}$ & 0.77 & $*$ \\
\hline Latin Switzerland & $\begin{array}{c}0.27 \\
(0.002)\end{array}$ & $\begin{array}{c}0.3 \\
(0.003)\end{array}$ & $\begin{array}{c}0.23 \\
(0.003)\end{array}$ & $\begin{array}{c}0.31 \\
(0.001)\end{array}$ & 0.31 & $*$ \\
\hline Wage & $\begin{array}{l}104549 \\
(575.8)\end{array}$ & $\begin{array}{l}108419 \\
(840.9)\end{array}$ & $\begin{array}{c}99574 \\
(749.34)\end{array}$ & $\begin{array}{c}81907 \\
(346.73)\end{array}$ & 87175 & $*$ \\
\hline Management position & $\begin{array}{c}0.44 \\
(0.003)\end{array}$ & $\begin{array}{c}0.42 \\
(0.004)\end{array}$ & $\begin{array}{c}0.47 \\
(0.004)\end{array}$ & $\begin{array}{c}0.27 \\
(0.001)\end{array}$ & 0.31 & $*$ \\
\hline Number of observations & 34630 & 19480 & 15150 & 114186 & 148816 & \\
\hline
\end{tabular}

Standard errors in parentheses. * Difference in means between PET and VET significant at the $1 \%$ level

Table 2: Probit regression of the probability of completing a PET programme, marginal effects

\begin{tabular}{lccc} 
& PET & PC & PE \\
\cline { 2 - 4 } Age & 0.004 & 0.006 & 0.003 \\
& $(0.001)^{*}$ & $(0.001)^{*}$ & $(0.001)^{*}$ \\
Age square & -0.0001 & -0.0001 & -0.00004 \\
& $(0)^{*}$ & $(0)^{*}$ & $(0)^{*}$ \\
Male & 0.12 & 0.09 & 0.05 \\
Swiss & $(0.003)^{*}$ & $(0.002)^{*}$ & $(0.002)^{*}$ \\
& 0.05 & 0.01 & 0.05 \\
Latin Switzerland & $(0.002)^{*}$ & $(0.002)^{*}$ & $(0.002)^{*}$ \\
& -0.039 & 0.0004 & -0.04 \\
\end{tabular}

Standard errors in parentheses.

* significant at $1 \%$ level, ** significant at $5 \%$ level, + significant at $10 \%$ level

Other controls include: marital status, branch or field of work, job position (management or not), year and tenure 
Table 3: Wage effects of PET

\begin{tabular}{|c|c|c|c|c|}
\hline & \multicolumn{2}{|c|}{$\mathrm{OLS}^{1}$} & \multicolumn{2}{|c|}{ Fixed effects } \\
\hline & (1) & (2) & (1) & (2) \\
\hline PET & $\begin{array}{c}0.21 \\
(0.003)^{*}\end{array}$ & & $\begin{array}{c}0.05 \\
(0.02)^{*}\end{array}$ & \\
\hline Professional college & & $\begin{array}{c}0.25 \\
(0.004)^{*}\end{array}$ & & $\begin{array}{c}0.07 \\
(0.02)^{*}\end{array}$ \\
\hline Professional examinations & & $\begin{array}{c}0.16 \\
(0.004)^{*}\end{array}$ & & $\begin{array}{c}0.03 \\
(0.02)+\end{array}$ \\
\hline Age & & $\begin{array}{c}0.02 \\
(0.002)^{*}\end{array}$ & & $\begin{array}{c}0.08 \\
(0.02)^{*}\end{array}$ \\
\hline Age square & & $\begin{array}{c}-0.0002 \\
(0.00002)^{*}\end{array}$ & & $\begin{array}{c}-0.001 \\
(0.0002)^{*}\end{array}$ \\
\hline Constant & $\begin{array}{c}10.49 \\
(0.03)^{*}\end{array}$ & $\begin{array}{c}10.49 \\
(0.03)^{*}\end{array}$ & $\begin{array}{c}9.62 \\
(0.54)^{*}\end{array}$ & $\begin{array}{c}9.64 \\
(0.54)^{*}\end{array}$ \\
\hline Number of observations & 148816 & 148816 & 4081 & 4081 \\
\hline
\end{tabular}

Standard errors in parentheses

* significant at $1 \%$ level, ** significant at $5 \%$ level, + significant at $10 \%$ level

${ }^{1}$ Other controls include: Nationality, gender, marital status, region of residence, branch or field of work, job position (management or not), year and tenure.

Table 4: Returns to professional college

\begin{tabular}{lcccccc}
\cline { 2 - 6 } & \multicolumn{7}{c}{ Wage effects: $\beta 1$} \\
\cline { 2 - 7 } & \multicolumn{2}{c}{$7 \%$} & \multicolumn{2}{c}{$15 \%$} & \multicolumn{2}{c}{$25 \%$} \\
\cline { 2 - 7 } & PV & Returns & PV & Returns & PV & Returns \\
\hline \multirow{2}{*yyyyyy}{ 1) Not working, paying all costs } & 2582673 & 36836 & 2810494 & 264658 & 3122137 & 576300 \\
& & 1.42 & & 9.42 & 18.46 \\
2) Working 50\%, paying 50\% & 2659025 & 113189 & 2886847 & 341010 & 3198489 & 652653 \\
& & 4.26 & & 11.81 & & 20.4 \\
3) Working 80\%, paying 50\% & 2730350 & 184513 & 2957181 & 412335 & 3269814 & 723977 \\
& & 6.76 & & 13.94 & & 22.14 \\
4) Working 100\%, paying 0 & 2735377 & 189541 & 2963199 & 417362 & 3274841 & 729005 \\
& & 7.44 & & 16.39 & & 28.64
\end{tabular}

$\mathrm{i}=0.3$

For case 1 the breaking point would be around $6 \%$.

For case 2 the breaking point would be between $2.5 \%$ and $3 \%$

Present value of earnings with secondary level VET: $2545836 \mathrm{CHF}$.

Net benefits in case 1 turn negative with 7\% return and interest rates above 4\%.

All other cases remain positive even increasing the interest rate up to $9 \%$. 
Table 5: Returns to professional examinations

\begin{tabular}{|c|c|c|c|c|c|c|}
\hline & \multicolumn{6}{|c|}{ Wage effects: $\beta 1$} \\
\hline & \multicolumn{2}{|c|}{$3 \%$} & \multicolumn{2}{|c|}{$10 \%$} & \multicolumn{2}{|c|}{$16 \%$} \\
\hline & PV & Returns & PV & Returns & PV & Returns \\
\hline $\begin{array}{l}\text { 1) Not working, } \\
\text { paying all costs }\end{array}$ & $2,440,000$ & $\begin{array}{c}-93254 \\
-3.68\end{array}$ & 2629619 & $\begin{array}{c}96363 \\
3.8\end{array}$ & 2803055 & $\begin{array}{c}269799 \\
10.65\end{array}$ \\
\hline $\begin{array}{l}\text { 2) Working } 50 \% \text {, } \\
\text { paying } 50 \%\end{array}$ & 2527567 & $\begin{array}{l}-5687 \\
-0.22\end{array}$ & 2717186 & $\begin{array}{c}183930 \\
7.26\end{array}$ & 2890622 & $\begin{array}{c}357366 \\
14.1\end{array}$ \\
\hline $\begin{array}{l}\text { 3) Working } 80 \% \text {, } \\
\text { paying } 50 \%\end{array}$ & 2577767 & $\begin{array}{c}44512 \\
1.75\end{array}$ & 2767386 & $\begin{array}{c}234130 \\
9.24\end{array}$ & 2940822 & $\begin{array}{c}407567 \\
16.09\end{array}$ \\
\hline $\begin{array}{l}\text { 4) Working } 100 \% \text {, } \\
\text { paying } 0\end{array}$ & 2615134 & $\begin{array}{l}81879 \\
3.23\end{array}$ & 2804753 & $\begin{array}{c}271497 \\
10.72\end{array}$ & 2978189 & $\begin{array}{c}444933 \\
17.56\end{array}$ \\
\hline
\end{tabular}

$\mathrm{i}=0.3$

For case 4 the breaking point would be between $1 \%$ and $1.5 \%$.

For case 2 the breaking point would be between $3.2 \%$ and $3.3 \%$.

The net benefits in case 4 are still positive in all cases even with interest rates up to $7 \%$.

The net benefits in case 2 are still positive with returns above $6 \%$ even with interest rates up to $7 \%$.

Present value of earnings with secondary level VET: CHF 2,533,255 